\title{
TINJAUAN FIKIH EKONOMI TERHADAP PENGUPAHAN BAJAK SAWAH DI NAGARI PADANG LAWEH MALALO KECAMATAN BATIPUAH SELATAN KABUPATEN TANAH DATAR
}

\author{
Rizki Fadli ${ }^{1}$, Zainuddin ${ }^{2}$ \\ 1 Pascasarjana Institut Agama Islam Negeri Batusangkar, Email: rizkifadli875@gmail.com \\ 2Pascasarjana Institut Agama Islam Negeri Batusangkar, Email : \\ zainuddin@iainbatusangkar.ac.id
}

\begin{abstract}
ABSTRAK
Artikel ini membahas tentang pengupahan bajak sawah menurut perspektif fikih ekonomi di Nagari Padang Laweh Malalo Kecamatan Batipuah Selatan Kabupaten Tanah Datar. Permasalahannya adalah telah terjadi perubahan tradisi membajak sawah dari menggunakan sapi kepada menggunakan mesin traktor. Perubahan ini membawa perubahan pula terhadap pelaksanaan membajak, efesiensi waktu, biaya, dan cara penghitungan upah. Tujuan penelitian ini meninjauan fikih ekonomi terhadap pengupahan bajak sawah di Nagari Padang Laweh Malalo Kecamatan Batipuah Selatan Kabupaten Tanah Datar. Jenis penelitian yang penulis gunakan adalah penelitian kepustakaan dengan pendekatan deskriptif kualitatif. Data yang penulis dapatkan adalah melalui wawancara. Sumber data adalah petani baik yang punya sawah maupun yang tukang bajak. Data diolah dengan cara mengklasifikasikan atau mengkategorikan data dan dianalisis dengan teori fikih ekonomi. Penelitian ini menemukan bahwa tinjauan fikih ekonomi terhadap pengupahan bajak sawah di Nagari Padang Laweh Malalo Kecamatan Batipuah Selatan Kabupaten Tanah Datar hukumnya boleh (mubah) karena penambahan upah yang diminta tukang bajak menggunakan mesin sesuai dengan hasil pekerjaan yang dihasilkannya dan sesuai dengan Al-Qur'an.
\end{abstract}

Kata-Kata Kunci: Pengupahan; Membajak Sawah; Fikih Ekonomi

\section{ABSTRACT}

This article discusses the payment of rice plow from the perspective of Economic Jurisprudence in Nagari Padang Laweh Malalo, Kecamatan Batipuah Selatan, Kabupaten Tanah Datar. The problem is that there has been a change in the tradition of plowing rice fields from using cattle to using tractor engines. These changes also bring changes to the practice of plowing, the efficiency of time, costs, and how wages are calculated. The purpose of this study was to examine the economic figh of the wages of rice plows in Nagari Padang Laweh Malalo Kecamatan Batipuah Selatan Kabupaten Tanah Datar. The type of research I use is library research with a qualitative descriptive approach. The data that the author gets is through interviews. Data sources are farmers who have rice fields or plowsmen. Data is processed by classifying or categorizing the data and analyzed with the theory of Economic Jurisprudence. This study found that the Review of Economic Jurisprudence on wage plows in Nagari Padang Laweh Malalo, Kecamatan Batipuah Selatan, Kabupaten Tanah Datar may 
be permissible (mubah) due to the addition of wages requested by the plowman to use the machine in accordance with the work produced and in accordance with the Qur'an.

Keywords: Wages; Rice Plowing; Economic Jurisprudence

\section{PENDAHULUAN}

Perekonomian adalah faktor yang sangat penting dan berpengaruh ditengah kehidupan masyarakat. Berbicara tentang ekonomi sudah pasti salah satunya membahas tentang sumber-sumber ekonomi, baik sumber primer, seperti pertanian, perindustrian, perdagangan, dan tenaga manusia (jasa) maupun sumber sekunder, seperti pariwisata, gaji (salary), dan sarana transportasi (Al Maliki, 2001). Kedua sumber tersebut tidak bisa lepas dari pelaku ekonomi, yaitu manusia. Melalui tenaga manusia sumber-sumber tersebut dapat dijalankan dan dirasakan manfaatnya baik dalam bentuk barang ataupun jasa dikarenakan manusia yang mempunyai kemampuan untuk memproduksi barang, bercocok taman, melakukan transaksi jual beli dan sebagainya.

Dalam artikelnya Zainuddin, dkk. (2017) menuliskan delapan prinsip yang perlu diperhatikan dalam bermuamalah, yaitu: pertama, tidak mencari rezeki yang haram dan tidak pula menggunakannya diharamkan. Kedua, tidak menzalimi dan tidak dizalimi. Ketiga, keadilan pendistribusian kemakmuran. Keempat, transaksi dilakukan atas dasar ridha (suka sama suka). Kelima, tidak mengandung unsur riba(tambahan atas harta pokok tanpa adanya transaksi yang melegitimasi adanya penambahan tersebut secara adil sesuai syariah. Keenam, tidak mengandung unsur maisyir (perjudian). Ketujuh, tidak mengandung unsur gharar (ketidakjelasan/samar-samar). Kedelapan, tidak mengandung ke-mudharatan dan mafsadat (sesuatu yang dapat mendatangkan kemudaratan dan kerusakan).

Dalam hubungan kerja, satu pihak ada yang sebagai penyedia jasa manfaat atau tenaga yang disebut buruh dan akan mendapatkan kompensasi berupa upah, serta sebagai pihak yang menyediakan pekerjaan yang disebut majikan. Dalam literatur fiqh dinamakan sewa menyewa jasa tenaga manusia, yang disebut akad ijārah al-'amal, (جارة العمل ) yaitu ijarah dengan cara memperkerjakan seseorang untuk melakukan sesuatu (Afandi, 2009). Kompensasi dalam bentuk upah terjadi dalam banyak kegiatan 
ekonomi, salah satunya dalam kegiatan pertanian. Dalam pertanian setiap orang yang bekerja di sawah orang lain akan mendapatkan imbalan berupa upah sesuai dengan kesepakatan atau sesuai dengan kebiasaan yang terjadi di daerah setempat, yang menimbulkan keanakaragaman bentuk cara pengupahan.

Pengupahan dalam kegiatan pertanian ini juga terjadi di Jorong Padang Laweh, Nagari Padang Laweh Malalo. Pengupahan sawah yang terjadi di Jorong Padang Laweh merupakan hal yang unik, dimana penentuan upah bajak sawah pakai mesin traktor dihitung berdasarkan konversi dari upah bajak dengan menggunakan sapi. Upah ini tidak dihitung berdasarkan hari bekerja menggunakan mesin tersebut. Bahkan pembajak dengan mesin meminta lebih satu hari dari konversi membajak dengan sapi. Apabila hal ini tidak disetujui pemilik sawah maka pembajak dengan mesin tidak bersedia membajak sawah tersebut. Akhirnya yang punya sawah terpaksa menyetujui karena takut sawahnya tidak ada yang akan membajaknya.

Berdasarkan data awal yang penulis dapatkan di Jorong Padang Laweh tidak ada lagi orang menggunakan sapi untuk membajak sawah sejak 8 tahun terakhir. (Yus Efendi, Kepala Jorong Padang Laweh). Berdasarkan latar belakang pemikiran di atas, timbul pertanyaan ,bagaimana tinjauan fikih ekonomi terhadap pengupahan bajak sawah di Nagari Padang Laweh Malalo Kecamatan Batipuah Selatan Kabupaten Tanah Datar?.

\section{METODE PENELITIAN}

Penelitian ini menggunakan penelitian lapangan. Metode yang dipakai adalah metode penelitian hokum normative yang bersifat deskriptif kualitatif. Artinya disini penulis mengambarkan secara jelas peristiwa-peristiwa hukum tentang pengupahan membajak dengan mesin di Jorong Padang Laweh Nagari Padang Laweh Malalo dan mengkonfimasinya kepada norma atau aturan hukum Islam yang dalam hal ini fikih ekonomi. Sumber datanya adalah petani baik yang punya sawah maupun yang tukang bajak. Data diolah dengan cara mengklasifikasikan atau mengkategorikan data dan dianalisis dengan fikih ekonomi. Kajian fikih ekonomi yang penulis gunakan berlandaskan kepada ayat-ayat AlQuran dan Hadits. 


\section{HASIL DAN PEMBAHASAN}

\section{Pengertian Ijarah}

Ijārah ( اجارة ) berarti sewa, jasa, atau imbalan. Secara etimologi ijārah ( ( اجارة adalah menjual manfaat. Menurut ulama Hanafiah ijārah ( اجارة), adalah akad atas suatu kemanfaatan dengan pengganti. Menurut Ulama Asy-Syafi'iyah ijärah (ارة) adalah akad atas suatu kemanfaatan yang mengandung maksud tertentu, serta menerima pengganti atau kebolehan dengan pengganti tertentu. (Hidayati, 2017). Menurut Fatwa Dewan Syariah Nasional, ijārah (اجارة) adalah akad pemindahan hak guna (manfaat) atas suatu barang atau jasa dalam waktu tertentu melalui pembayaran sewa/upah, tanpa diikuti dengan pemindahan kepemilikan barang itu sendiri. Di dalam istilah hukum Islam orang yang menyewakan disebut "mu'ajjir", sedangkan orang yang menyewa disebut dengan "musta'jir"( ( مستأجر ), benda yang disewakan diistilahkan " $m a^{\prime} j \bar{u} r$ " dan uang sewa atau imbalan atas pemakaian manfaat barang tersebut disebut "ujrah" (Pasaribu, 1994).

Ada yang menerjemahkan, ijarah sebagai jual-beli jasa (upahmegupah), yakni mengambil manfaat tenaga manusia. Ada pula yang menerjemahkan sebagai sewa-menyewa yakni mengambil manfaat dari barang. Ijarah pada hakikatnya adalah hubungan saling memerlukan antara dua orang/pihak, majikan/pengusaha dan buruh. Kedua pihak saling memberi manfaat/ kepentingan. Majikan memberi upah, dan buruh memberikan tenaganya. (Hasan, 2003). Khumedi Jafar (2016) mengatakan upah adalah harga yang dibayarkan kepada pekerja atas jasanya dalam produksi kekayaan seperti faktor produksi lainnya, tenaga kerja diberi imbalan atas jasanya yang disebut upah. Dengan kata lain, upah adalah memberikan imbalan sebagai bayaran kepada seseorang yang telah diperintahkan untuk mengerjakan suatu pekerjaan tertentu dan bayaran itu diberikan menurut perjanjian yang telah disepakati.

\section{Dasar Hukum Ijarah}

Berikut adalah dasar atau dalil yang membahas tentang upah :

a. Surat At-Thalaq ayat 6

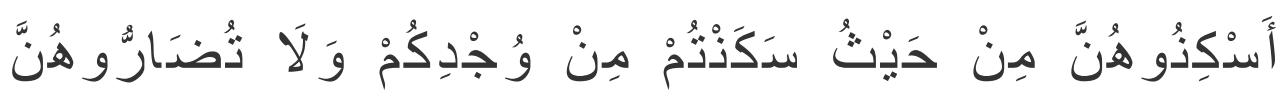




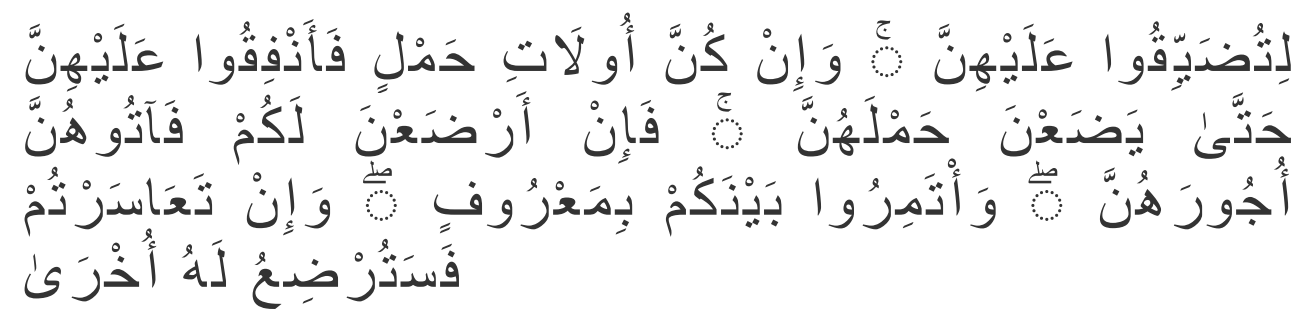

Artinya : "Tempatkanlah mereka (para isteri) di mana kamu bertempat tinggal menurut kemampuanmu dan janganlah kamu menyusahkan mereka untuk menyempitkan (hati) mereka. Dan jika mereka (isteri-isteri yang sudah ditalaq) itu sedang hamil, maka berikanlah kepada mereka nafkahnya hingga mereka bersalin, kemudian jika mereka menyusukan (anak-anak)mu untukmu maka berikanlah kepada mereka upahnya, dan musyawarahkanlah di antara kamu (segala sesuatu) dengan baik; dan jika kamu menemui kesulitan maka perempuan lain boleh menyusukan (anak itu) untuknya."

Dalam ayat di atas terdapat kata fa'tuhunna ujurahunna. AshShabuni mengatakan maka menjadi kewajiban ayah untuk membayar upah susuan (al-radha'at). Argumentasi yang dikembangkannya adalah karena anak-anak yang lahir tersebut dinasabkan kepada ayah (Tarigan, 2012). Dalam konteks ini point penting yang dikemukakan ayat ini adalah, kata ajr (ujur) merupakan hak bagi pekerja dan kewajiban bagi orang yang memperkerjakan seseorang. Sampai-sampai, untuk seorang ibu yang telah di-thalaq suaminya berhak menerima upah susuan dari suaminya walau terhadap anaknya sendiri. Demikian juga kalau suaminya menyewa ibu susuan lain, menjadi kewajibannyalah untuk menyiapkan upah yang layak. (Tarigan, 2012 )

b. Surat Al-Qhasas ayat 27

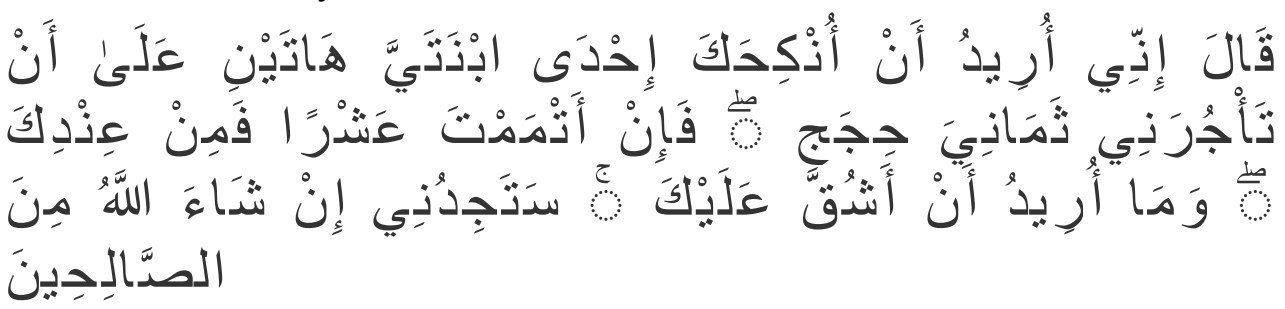

Artinya: Berkatalah dia (Syu'aib): "Sesungguhnya aku bermaksud menikahkan kamu dengan salah seorang dari kedua anakku ini, atas dasar bahwa kamu bekerja denganku delapan tahun dan jika kamu cukupkan 
sepuluh tahun maka itu adalah (suatu kebaikan) dari kamu, maka aku tidak hendak memberati kamu. Dan kamu Insya Allah akan mendapatiku termasuk orang-orang yang baik".

Kata ta'jurani pada ayat di atas dibeberapa terjemah dimaknakan "engkau bekerja denganku". Dapat juga diartikan, "engkau mengambil upah denganku". Ada yang menarik dari ayat ini, Syu'aib memberi tawaran kepada Nabi Musa-setelah Nabi Musa mengadukan perihal atau kondisi yang sedang menimpanya, karena hendak dibunuh oleh Fir'aun-untuk bekerja dengannya. Seakan Nabi Syu'aib mengontrak Musa bisa 8 tahun atau bisa juga 10 tahun. Kata-kata wa ma uriduan asyuqqa 'alaika, menandakan tidak ada paksaan dalam kesepakatan kerja. Dengan kata lain, bentuk pekerjaan atau upah yang bakal diterima tidak boleh memberatkan bagi si pekerja. Harus ada kerelaan untukmenerima apa yang diperjanjikan.

Pesan ayat ini sesungguhnya, kita boleh menawarkan pekerjaan kepada orang lain. Lebih baik lagi jika tawaran-tawaran itu mengandung beberapa alternatif, sehingga buruh yang akan bekerja bisa mempertimbangkan dirinya untuk memilih mana yang lebih mungkin dan sanggup ia kerjakan. (Tarigan, 2012)

c. Surat Al-Ahakaf ayat 19

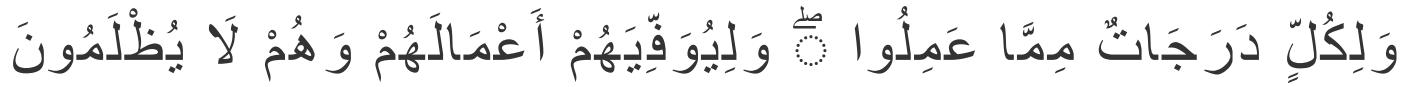

Artinya : Dan bagi masing-masing mereka derajat menurut apa yang telah mereka kerjakan dan agar Allah mencukupkan bagi mereka (balasan) pekerjaan-pekerjaan mereka sedang mereka tiada dirugikan.

Kata derajat di atas menunjukkan tentang hasil atau kedudukan yang akan diperoleh oleh manusia bahwa hal itu didasarkan pada hasil kinerja mereka. Jika dikaitkan dengan transaksi ijarah dapat disimpulkan bahwa upah yang diperoleh oleh seseorang akan berbeda dengan upah yang didapatkan oleh orang lainnya sesuai dengan hasil kinerja yang mereka lakukan. Islam memberikan solusi yang tepat bagi permasalahan upah untuk menyelamatkan kepentingan kedua belah pihak antara pemberi upah dengan penerima upah, agar hak dan kewajiban keduanya terpenuhi. Upah ditetapkan dengan cara yang tepat tanpa harus 
menindas pihak manapun. Setiap pihak memperoleh bagian yang sah dari hasil kerja sama mereka tanpa adanya penganiayaan atau ketidak adilan terhadap pihak lain. (Ru'fah Abdullah, 2011)

\section{Rukun Ijarah}

Ijarah sebagai sebuah transaksi umum baru dianggap sah apabila telah memenuhi syarat dan rukunnya. Menurut ulama Mazhab Hanafi, rukun ijarah hanya ijab dan qabul. Akan tetapi, jumhur ulama berpendapat bahwa rukun ijarah itu yaitu :

a. Sighah ijarah yaitu ijab dan qabul berupa pernyataan dari kedua belah pihak yang berakat (berkontrak) baik secara verbal atau dalam bentuk lain.

b. Pihak-pihak yang berakad, terdiri atas pemberi sewa/pemberi jasa atau penyewa/pengguna jasa. Mu'jir dan musta'jir, yaitu orang yang melakukan akad sewa menyewa atau upah-mengupah. Mu'jir adalah yang memberikan upah dan yang menyewakan, musta'jir adalah orang yang menerima upah untuk melakukan sesuatu dan yang menyewa sesuatu, disyaratkan pada $m u^{\prime} j i$ ir dan $m u s t a ' j i r$ adalah baligh, berakal cakap melakukan tasharruf (mengendalikan harta), dan saling meridhai.

c. Objek akad ijarah

1) Manfaat barang atau sewa;

2) Manfaat jasa dan upah. Upah atau ujrah, disyaratkan diketahui jumlahnya oleh kedua belah pihak baik dalam sewa-menyewa maupun dalam upah-mengupah. (Mustofa, 2016)

4. Syarat Ijarah

Syarat ijarah ada empat macam, yaitu syarat terjadinya akad, (syurut alin 'iqad), syarat pelaksanaan ijarah (syarat al-nafadz), syarat sah (syurut alshihah), dan syarat mengikat (syarat al-luzum). Adanya syarat-syarat ini dimaksudkan untuk menjamin bahwa ijarah yang akan dilakukan mendatangkan kebaikan bagi para pihak yang melakukannya. Antara lain, yakni:

a. Syarat terjadinya akad. Menurut madzhab Syafieci dan Hanbali, dikutip M. Yazid Afandi bahwa kedua orang yang berakad telah berusia aqil baligh, sementara menurut madzhab Hanafi dan Maliki, 
orang yang berakad cukup pada batas mumayyiz dengan syarat mendapatkan persetujuan wali. Bahkan golongan Syafi'iyah memasukkan persyaratan pada akid termasuk Rusyd. Yaitu mereka mampu melakukan sesuatu atas dasar rasionalitas dan kredibilitasnya. Maka, menurut imam Syafi'i dan Hanbali seorang anak kecil yang belum baligh, bahkan imam Syafi'i menambahkan sebelum Rusyd tidak dapat melakukan akad ijarah. Berbeda dengan kedua imam tersebut, imam Abu Hanifah membolehkan asalkan dia sudah mumayyiz dan atas seizin orang tuanya. (M. Yazid, 2009).

b. Syarat pelaksanaan. Syarat pelaksanaan ijarah, akad ijarah dapat terlaksana bila ada kepemilikan dan penguasaan, karena tidak sah akad ijarah terhadap barang milik atau sedang dalam penguasaan orang lain. Tanpa adanya kepemilikan dan atas penguasaan, maka ijarah tidak sah.

c. Syarat sah ijarah. Syarat ini ada terkait dengan para pihak yang berakad, objek akad dan upah. Syarat sah sebagai berikut:

1) Adanya keridaan dari kedua belah pihak yang akad. Ada kerelaan pada kedua belah pihak atau tidak ada paksaan. Orang yang sedang melakukan akad ijarah berada pada posisi bebas untuk berkehendak, tanpa ada paksaan salah satu atau kedua belah pihak oleh siapapun. (M. Yazid, 2009)

2) Ma'qud alaih bermanfaat dengan jelas. Adanya kejelasan pada $m a^{\prime} q u d$ alaih (barang) menghilangkan pertentangan diantara 'aqid. Diantara cara untuk mengetahui ma'qud alaih (barang) adalah dengan menjelaskan manfaatnya, pembatasan waktu, atau menjelaskan jenis pekerjaan jika ijarah atas pekerjaan atau jasa seseorang :

a) Penjelasan jenis pekerjaan, penjelasan tentang jenis pekerjaan sangat penting dan diperlukan ketika menyewa orang untuk bekerja sehingga tidak terjadi kesalahan atau pertentangan.

b) Penjelasan waktu kerja, tentang batasan waktu kerja sangat bergantung pada pekerjaan dan kesepakatan dalam akad.

c) Syarat yang terkait dengan upah atau uang sewa adalah upah harus berharga dan jelas bilangan atau ukurannya.

d) Syarat terkait dengan manfaat barang atau jasa seseorang ada tujuh, yaitu: 
(1) Manfaat barang harus mubah atau tidak dilarang syarat ini untuk menghindari penyewaan barang atau jasa yang terlarang.

(2) Manfaat barang atau jasa bisa diganti dengan materi.

(3) Manfaat barang atau jasa merupakan suatu yang berharga dan ternilai

(4) Manfaat merupakan suatu yang melekat pada barang yang sah kepemilikannya.

(5) Manfaat barang objek sewa bukan untuk menghasilkan barang, seperti menyewa pohon untuk diambil buahnya, sewa macam ini tidak sah termasuk dalam pengecualian syarat ini sewa jasa menyusui, karena darurat dalam hadanah.

(6) Manfaat dapat diserah terimakan

(7) Manfaat harus jelas dan dapat diketahui. (Mustofa, 2016)

d. Syarat lazim atau syarat mengikat. Ijarah adalah jenis akad lazim, yaitu akad yang tidak membolehkan adanya fasakh (batal) pada salah satu pihak (Syafei, 2001). Syarat yang mengikat ini ada dua syarat, yaitu:

1) Barang atau orang yang disewakan harus terhindar dari cacat yang dapat menghilangkan fungsinya. Apabila susudah transaksi terjadi cacat pada barang, sehingga fungsinya tidak maksimal, atau bahkan tidak berfungsi, maka penyewa berhak memilih untuk melanjutkan atau menghentikan akad sewa. Bila suatu ketika barang yang disewakan mengalami kerusakan maka akad ijarah fasakh atau rusak dan tidak mengikat kedua belah pihak.

2) Terhindarnya akad dari udzur yang dapat merusak akad ijarah. Udzur ini bisa terjadi pada orang atau pihak yang berakad atau pada objek akad ijarah.

\section{Macam-Macam Ijarah}

Akad al-ijarah dibagi para ulama kepada dua macam, yaitu: yang bersifat manfaat dan yang bersifat pekerjaan (jasa) al-ijarah yang bersifat manfaat, umpamanya adalah sewa menyewa rumah, toko, kendaraan, pakaian, dan perusahaan. Apabila manfaat itu merupakan manfaat yang dibolehkan syara' untuk dipergunakan, maka para ulama fikih sepakat 
menyatakan boleh dijadikan objek sewa menyewa.

Al-ijarah yang bersifat pekerjaan ialah dengan cara mempekerjakan seseorang untuk melakukan suatu pekerjaan. Al-ijarah seperti ini, menurut para ulama fikih, hukumnya boleh apabila jenis pekerjaan itu jelas, seperti buruh bangunan, tukang jahit, buruh, pabrik, dan tukang sepatu. Al-ijarah seperti ini, ada yang bersifat pribadi, seperti menggaji seorang pembantu rumah tangga, dan yang bersifat serikat, yaitu seseorang atau sekelompok orang yang menjual jasanya untuk kepentingan orang banyak, seperti tukang sepatu, buruh pabrik, dan tukang jahit. Keduanya bentuk al-ijarah terhadap bentuk pekerjaan ini (buruh, tukangdan pembantu, menurut ulama fiqh, hukumnya boleh. upah mengupah atau ijarah 'ala al-a'mal, yakni jual-beli jasa, biasanya berlaku dalam beberapa hal seperti menjahitkan pakaian, membangun rumah, dan lain-lain. Ijarah ala' al-a'mal terbagi dua, yaitu:

a. Ijarah Khusus. Yaitu ijarah yang dilakukan oleh seorang pekerja. Hukumnya, orang yang bekerja tidak boleh bekerja selain dengan orang yang telah memberinya upah.

b. Ijarah Mussytarik. Yaitu ijarah dilakukan secara bersama-sama atau melalui kerja sama. Hukumnya diperbolehkan bekerja sama dengan orang lain. ( Nasroen, 2007)

6. Berakhirnya Akad Ijarah

Para ulama figh menyatakan bahwa akad al-ijrah akan berakhir apabila:

a. Obyek hilang atau musnah, seperti rumah terbakar atau baju yang dijahitkan hilang.

b. Tenggang waktu yang disepakati dalam akad al-ijarah telah berakhir. Apabila yang disewakan itu rumah, maka rumah itu dikembalikan kepada pemiliknya, dan apabila yang disewa itu jasa seseorang, maka ia berhak menerima upahnya. Kedua hal ini disepakati oleh seluruh ulama figh.

c. Menurut ulama Hanafiyah, wafatnya salah seorang yang berakad, karena akad al-ijarah, menurut mereka, tidak boleh diwariskan. Sedangkan menurut jumhur ulama, akad al-ijarah tidak batal dengan wafatnya salah seorang yang berakad, karena manfaat, menurut mereka, boleh diwariskan dan al-ijarah sama dengan jual beli, yaitu mengikat kedua belah pihak yang berakad. 
Menurut ulama Hanafiyah, apabila uzur dari salah satu pihak, seperti rumah yang disewakan disita negra karena terkait utang yang banyak, maka akad al-ijarah batal. Uzur-uzur yang dapat membatalkan akad al-ijarah itu, menurut ulama Hanafiyah adalah salah satu pihak jatuh muflis, dan berpindah tempatnya penyewa, misalnya, seseorang digaji untuk menggali sumur di suatu desa, sebelum sumur itu selesai, penduduk desa itu pindah kedesa lain. Akan tetapi, menurut jumhur ulama, uzur yang boleh membatalkan akad al-ijarah itu hanyalah apabila obyeknya mengandung cacat atau manfaat yang dituju dalam akad itu hilang, seperti kebakaran dilanda banjir. (Nasroen, 2007).

\section{Pengupahan dalam Pandangan Hukum Ekonomi Islam}

Dalam hukum Islam pengupahan termasuk ke dalam Ijārah al-'amal ( (اجارةالعمل. Upah dapat menjadi sebab adanya kepemilikan, dengan gambaran bahwa upah merupakan mediasi mencari harta (At-Tariqi, 2004). Dalam Al-Qur'an, besar minimal gaji memang tidak disebutkan atau tidak ditentukan secara terperinci, tetapi secara tegas Allah SWT mewajibkan kepada seseorang (pengelola perusahaan) untuk membayar gaji karyawan yang dipekerjakannya. Sedangkan besaran gaji dalam Islam harus ditetapkan melalui kesepakatan antara karyawan dan pengusaha yang didasarkan pada prinsip keadilan. Islam memberikan perhatian dengan menetapkan tingkat upah minimum bagi pekerja atau buruh dengan cara memperhatikan nilai-nilai kelayakan dari upah.

Upah yang adil sebenarnya merupakan upah yang mengacu kepada jasa dari pekerja atau buruh yang dipengaruhi oleh beberapa hal seperti jumlah uang yang diterima, daya beli uang yang merupakan alat untuk memenuhi kebutuhan. Artinya upahkerja harus seimbang dengan jasa yang diberikan pekerja. Dalam penetapan upah atau imbalan, Islam tidak memberikan ketentuan secara eksplisit, akan tetapi penerapannya dapat dilakukan melalui pemahaman dan pemaknaan terhadap Al-Qur'an dan Hadis yang diwujudkan dalam nilai-nilai universal seperti prinsip keadilan, kelayakan, dan kebajikan.(Basyir, 1996). Mekanisme penetapan upah dalam konsep Islam terdapat tiga alternatif sebagai berikut: (Armansyah, 2017)

a. Mekanisme Musyawarah. Musyawarah merupakan pembahasan bersama dengan maksud mencapai keputusan atas penyelesaian 
masalah bersama. Maka upah kerja ditetapkan atas dasar keputusan bersama yang telah disepakati oleh pengusaha dan pekerja dengan syarat adanya keadilan dan kerelaan antara dua pihak yang bertransaksi.

b. Mekanisme pasar. Mekanisme ini menetapkan bahwa upah yang akan diterima pekerja disesuaikan dengan upah yang berlaku di pasaran (market wage), yaitu didasarkan pada penawaran dan permintaan tenaga kerja, serta nilai kontribusi tenaga kerja terhadap produktifitas (value of marginal product of labour). Namun dalam Islam tidak hanya didasarkan pada market wage dan value of marginal product of labour saja, tetapi juga harus disertai dengan pertimbangan-pertimbangan kemanusiaan (humanity). Oleh karena itu penentuan upah walaupun bergantung kepada aspek fiskal, kemahiran, latihan dan mental, akan tetapi juga mempertimbangkan aspek lainnya, yaitu aspek keperluan para pekerja dalam memenuhi kebutuhan hidup bagi diri dan keluarganya (Hassan, 2001:11). Mekanisme ini dilakukan jika kedua belah pihak tidak mencapai kesepakatan dalam penentuan upah, maka keduanya terikat pada keumuman upah yang berlaku dipasar untuk jenis pekerjaan yang sama. Namun demikian upah tidak bersifat abadi hanya berlaku pada saat tertentu yang telah disepakati atau dengan pekerjaan yang telah disepakati untuk dikerjakan(Al Maliki, 2001). Upah yang ditetapkan melalui mekanisme ini dikenal dengan ajru al-misl (upah yang sepadan).

c. Ditentukan oleh Negara. Negara (pemerintah) memainkan peranan penting dalam perekonomian, yaitu menjamin perekonomian berjalan sesuai dengan syari'ah dan menjamin agar tidak terjadi pelanggaran terhadap hak-hak asasi, semua ini dalam rangka mencapai maqashid asy-syari'ah sebagaimana disabdakan Rosulullah SAW “...Imam (kepala negara) itu laksana penggembala. Dia bertanggung jawab atas rakyatnya..." (Al Bukhori, 127). Karena itu jika dalam penetapan upah terjadi hal-hal yang dapat merugikan kehidupan salah satu pihak atau bahkan terjadi gejolak tidak sehat dalam masyarakat yang dapat mengancam kemaslahatan umum maka negara boleh ikut campur menyelesaikannya baik sebagai penengah maupun mengeluarkan peraturan dalam rangka menegakan keadilan. Di sinilah letak bahwa dalam ekonomi Islam 
selain bersifat etis juga bersifat normatif dalam artian peka-dampak (consequence-sensitive). Tugas negara adalah memastikan upah ditetapkan dengan tidak terlalu rendah sehingga menafikan kebutuhan hidup para pekerja, tetapi tidak juga terlalu tinggi sehingga menafikan bagian pemilik modal dari hasil produksi bersamanya (Afzalurrahman, 1995). Negara harus menetapkan batas minimum dan batas maksimum dalam pengupahan, adapun batasan mengenai upah tertinggih adalah sesuai dengan apa yang dikerjakan (Muhammad, 2005).

Keikutsertaan negara ini berdasarkan kesepakatan ulama diperbolehkan dalam masalah ketenagakerjaan, termasuk juga di dalamnya penentuan upah kerja. Ibnu Taimiyah berargumentasi bahwa keikutsertaan negara tersebut untuk mencegah terjadinya kedzaliman. Qardawi menyatakan Islam membuka pintu seluasluasnya bagi negara untuk menentukan kebijakan, peundang undangan dalam upaya mewujudkan apa yang dipandangnya sebagai kemaslahatan umum atau mengambil tindakan-tindakan untuk mencegah dan menanggulangi gejalah tertentu yang tidak sehat dengan syarat semua itu tidak bertentangan dengan ketentuan nas yang muhkam serta kaidah hukum yang tetap (Qardhawi, 748). Guna mengatasi perselisihan yang terjadi antara pengusaha dengan pekerja dibentuk wadah penyelesaian persengketaan perburuhan yang berbentuk perorangan maupun lembaga yang ditunjuk baik oleh kedua pihak. Wadah atau badan ini semacam "badan arbitrase" yang keputusannya diharapkan bersifat mengikat dan final. Adapun pihak-pihak yang duduk di dalam badan ini adalah orang-orang yang adil dan mereka yang memiliki keahlian dalam masalah perburuhan.

Berdasarkan hasil penelitian lapangan didapatkan bahwa pelaksanaan membajak di Jorong Padang Laweh adalah sebagai berikut:

\section{Menggunakan sapi}

Membajak sawah di Jorong Padang Laweh Nagari Padang Laweh Malalo sejak zaman dahulu menggunakan sapi. Sapi tersebut dipelihara dan diajar cara membajak yang benar. Setelah sapi tersebut sudah pandai membajak seseorang datang kepada pemiliknya untuk membajak 
sawahnya. Bentuk pengupahan membajak sawah ini ada 2 macam :

a. Sistem upah harian

Hak- hak yang didapatkan tukang bajak menggunakan sistem upah harian adalah berupa air putih untuk diminum,istirahat untuk makan snack (11.30-12.15), snack (kopi dan kue), istirahat untuk makan siang dan sholat (13.45-14.30) makan siang dan upah berdasarkan aturan kesawah di kampung waktu itu yaitu Rp. 50.000/hari. Sedangkan kewajibannya membajak sawah si pengupah dimulai pukul 08.00 sampai pukul 17.00. (Hanafi, Ketua Kelompok Tani, Wawancara tanggal 20 April 2020).

b. Sistem borongan

Hak-hak yang didapatkan tukang bajak menggunakan sistem upah borongan adalah air putih untuk diminum, snack (kopi dan kue), sedangkan untuk istirahat terserah situkang bajak. Waktu pekerjaan diserahkan sepenuhnya kepada si tukang bajak. Sedangkan upah tergantung kesepakatan kedua belah pihak dan tergantung banyaknya sawah yang terbajak (Hanafi, Ketua Kelompok Tani, Wawancara tanggal 20 April 2020). Tetapi semenjak tahun 2013 tidak ada lagi petani di Jorong Padang Laweh yang membajak sawahnya menggunakan sapi, dikarenakan zaman sudah canggih dan masyarakat beralih menggunakan mesin bajak/traktor (Yus Efendi, Kepala Jorong Padang Laweh, wawancara tanggal 15 April 2020).

2. Menggunakan mesin (traktor)

Penggunaan mesin (traktor) untuk membajak di Jorong Padang laweh sebenarnya sudah dimulai sejak tahun 2007, tetapi belum banyak yang menggunakan. Baru di tahun 2013 semua masyarakat petani menggunakan mesin bajak dan meninggalkan menggunakan sapi untuk membajak sawahnya. Hak yang didapatkannya yaitu, air minum, snack, makan siang. Sedangkan untuk waktu istirahat tidak dibatasi (Hanafi, Ketua Kelompok Tani, Wawancara tanggal 20 April 2020).

Bentuk pengupahan yang digunakan pada membajak pakai mesin ini hanya dengan cara borongan. Cara mengitung upahnya melihat berapa hari biasanya sawah yang akan dibajak tersebut jika dibajak menggunakan sapi. Bila membajak menggunakan sapi membutuhkan waktu 3 hari dengan upah Rp.50.000/hari,maka apabila menggunakan mesin bajak 
upahnya Rp. 150.000, walaupun hanya dalam waktu satu hari. Kemudian kebanyakan tukang bajak mesin ini meminta upah lebih satu hari dari yang biasanya tersebut. Jadi upah yang diminta tukang bajak adalah Rp. 200.000,-. Dan hal inilah yang sering dikeluhkan oleh yang punya sawah, tapi dikarenakan tukang bajak tidak ada lagi terpakasa yang punya sawah menyepakati saja (Yus Efendi, Kepala Jorong Padang Laweh, wawancara tanggal 15 April 2020)

Menurut salah seorang petani di Jorong Padang Laweh, bahwa memang kebanyakan petani atau yang punya sawah sering merasa terpaksa membayar upah kepada tukang bajak menggunakan traktor karena orang yang memiliki bajak mesin itu tidak banyak. Apabila menunggu tukang bajak yang lain takut akan ketinggalan untuk bercocok tanam yang berakibat buruknya hasil saat panen. Jadi karena hal itu banyak petani yang terpaksa menyetujui (Sarbaini, Petani, wawancara tanggal 10 Juni 2020).

Dari hasil wawancara di atas bentuk pengupahan dengan menggunakan mesin jauh lebih menguntungkan bagi yang punya sawah, pertama dari segi waktu sawahnya akan lebih cepat selesai, kedua biaya konsumsi akan lebih murah, karena sawah yang biasanya dikerjakan 3 hari menggunakan sapi dapat dikerjakan dalam waktu 1 hari menggunakan mesin dan tentu konsumsi yang biasanya 3 kali akan menjadi 1 kali. Oleh sebab itu pantaslah orang yang membajak menggunakan mesin meminta kelebihan upah, karena dia meminta sesuai dengan hasil pekerjaan yang dihasilkannya. Dan hal itu dikatakan Allah dalam surat Al-Ahkaf ayat 19:

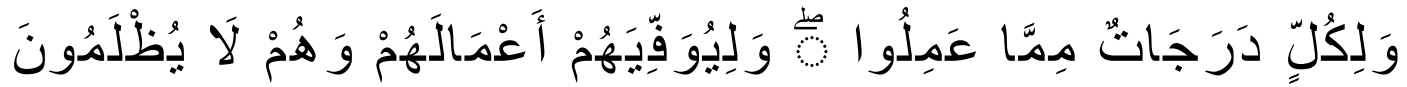

Artinya : Dan bagi masing-masing mereka derajat menurut apa yang telah mereka kerjakan dan agar Allah mencukupkan bagi mereka (balasan) pekerjaanpekerjaan mereka sedang mereka tiada dirugikan.

Ayat ini menjamin tentang upah yang layak kepada setiap pekerja sesuai dengan apa yang telah disumbangkan oleh pekerjaannya. Jika ada pengurangan dalam upah tanpa diikuti oleh berkurangnya sumbangsih hal ini dianggap sebagai ketidakadilan dan penganiayaan terhadap para pekerja. Sehingga ayat ini memperjelas bahwa upah setiap orang harus dibayarkan berdasarkan kerja dan sumbangsihnya dalam kerja sama produksi dan dibayar tidak kurang, juga tidak lebih dari apa yang telah 
dikerjakanya (Ridwan, 2008). Apabila yang punya sawah membayarkan upahmenggunakan mesin sama dengan menggunakan sapi tentu akan menimbulkan ketidakadilan bagi tukang bajak mesin tersebut dan ketidakadilan tersebut menimbulkan kezaliman, karena hal itu Allah melarangnya di dalam Al-Quran surat An-Nisa ayat 29. yaitu :

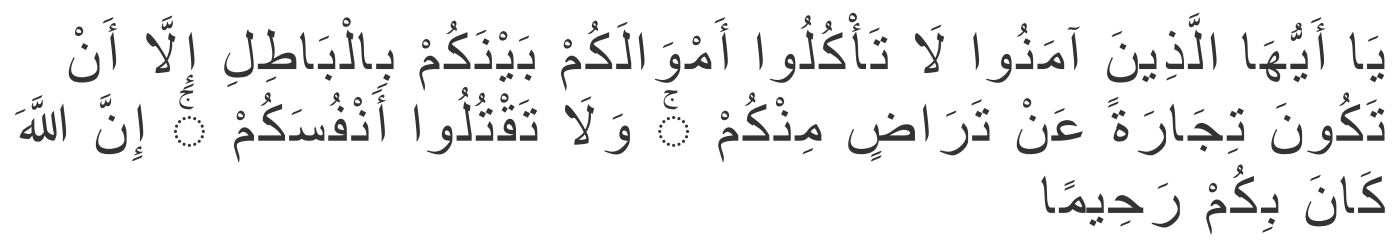

Artinya : "Hai orang-orang yang beriman, janganlah kamu saling memakan harta sesamamu dengan jalan yang batil, kecuali dengan jalan perniagaan yang berlaku dengan suka sama-suka di antara kamu. Dan janganlah kamu membunuh dirimu; sesungguhnya Allah adalah Maha Penyayang kepadamu".

Dari ayat ini Allah Swt melarang memakan harta sesama dengan cara yang dilarang oleh agama Islam. Allah menyuruh orang beriman dalam berniaga saling ridha diantara kedua belah pihak tanpa ada yang dirugikan. dan bagi tukang bajak menggunakan mesin saat meminta upah tidak boleh terlalu berlebihan yang nantinya akan memberatkan yang punya sawah. Karena Allah melarang sesuatu yang berlebihan itu dalam surat $A l-A^{\prime}$ raf ayat 31 :

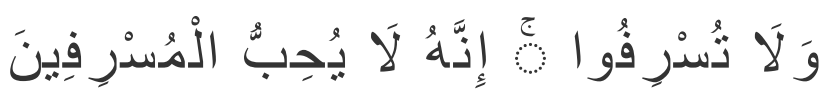

Artinya : ....dan janganlah berlebih-lebihan. Sesungguhnya Allah tidak menyukai orang-orang yang berlebih-lebihan.

Supaya tidak ada terjadi ketidakadilan bagi kedua belah pihak, baik bagi tukang bajak maupun yang punya sawah, islam mempunyai solusi terhadap hal tersebut yaitu Musyawarah seperti yang dikatakan oleh Armansyah (2017). Musyawarah merupakan pembahasan bersama dengan maksud mencapai keputusan atas penyelesaian masalah bersama. Maka upah kerja ditetapkan atas dasar keputusan bersama yang telah disepakati oleh pemberi kerja dan pekerja dengan syarat adanya keadilan dan kerelaan antara dua pihak yang bertransaksi.dan Allah juga mengatakan dalam surat At-Thalaq ayat 6:

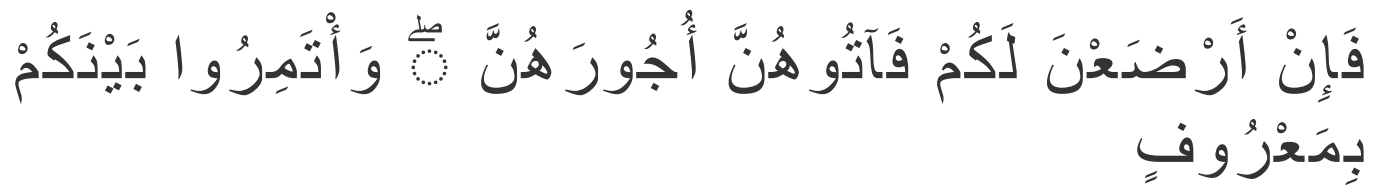


Artinya : "...jika mereka menyusui anak-anakmu berilah mereka upah, bermusyawarahlah diantara kamu dengan baik...".

Ayat tersebut menunjukan bahwa upah perlu ditentukan secara musyawarah yang ditafsirkan sebagai proses tawar menawar untuk menentukan kadar upah diterima kedua belah pihak. Memang ayat ini khusus ditujukan kepada penentuan upah kerja menyusui bayi, namun konsep musyawarah dalam Islam adalah bersifat umum dan karena itu satu prinsip umum penentuan upah boleh diperoleh daripada maksud ayat tersebut.

Penerapan mekanisme musyawarah ini mempunyai implikasi yang sangat jelas terhadap dunia perburuhan, karena memiliki bargaining position (posisi tawar menawar) yang sama dalam membuat kontrak kerja termasuk juga dalam hal upah. Musyawarah tersebut diperbolehkan untuk menyertakan syarat-syarat yang harus dipenuhi oleh kedua belah pihak selama tidak bertentangan dengan ketentuan syar'i. Mekanisme tersebut dilakukan untuk menghindari terjadinya perselisihan dikemudian hari karena salah satu pihak melakukan tindakan yang dapat merugikan pihak yang lain. Upah ditetapkan melalui mekanisme ini dikenal dengan ajru almusamma (upah yang disepakati). Muhammad Abdul Mannan berpendapat bahwa upah merupakan hak bagi pekerja yang ditentukan berdasarkan kesepakatan antara pekerja dengan majikan. Kesepakatan (kompromi) antara pekerja dan majikan dianggap sebagai prasyarat yang hakiki dalam menentukan upah kerja (Mannan, 1992:117).

\section{SIMPULAN}

Tinjauan fikih ekonomi terhadap pengupahan bajak sawah di Nagari Padang Laweh Malalo Kecamatan Batipuah Selatan Kabupaten Tanah Datar hukumnya boleh (mubah) karena penambahan upah yang diminta tukang bajak menggunakan mesin sesuai dengan hasil pekerjaan yang dihasilkannya dan sesuai dengan Al-Qur'an. Pembajak sawah tidak boleh meminta upah terlalu berlebihan kepada yang punya sawah karena Allah melarang sesuatu yang berlebihan. Supaya terjadi keadilan diantara kedua belah pihak Islam mempunyai solusi yaitu musyawarah.

\section{DAFTAR RUJUKAN}

Abdullah Abdul Husain At-Tariqi. 2004. Ekonomi Islam, Prinsip, Dasar, dan 
Tujuan, cet. ke-1 Yogyakarta: Magistra Insania Press

Afandi, M.Yazid. 2009. Figh Muamalah dan Implementasinya dalamLembaga Keuangan Syari'ah. Yogyakarta: Logung Pustaka

Afzalurrahman, 1995. Muhammad Sebagai Seorang Pedagang; Terjemahan oleh Dewi Nurjulianti, dkk., dari Muhammad: Encyclopedia of Seerah (1982). Jakarta: Yayasan Swarna Bhumy

Ahmad Azhar Basyir. 1996. Refleksi Atas Pemikiran Keislaman, cet. ke-4 Bandung: Mizan

Al-Bukhori, Abi Abdillah Muhammad ibnu Ismāīl. Tanpa Tahun. AlBukhori. Bairut: Dāru al-Kitāb al-Islāmī.

Al-Maliki, Abdurrahman. 2001. Politik Ekonomi Islam; Terjemahan oleh Ibnu Sholah, dari as-Siyasatu al-Iqtishadiyatu al-Mutsla. Bangil: AlIzzah.

Armansyah Waliam. 2017. Upah Berkeadilan Ditinjau dari Perspektif Islam. Jurnal Bisnis dan Manajemen. Vol. 5 , No 2

Azhari Ahmad Tarigan, 2012. Tafsir Ayat-Ayat Ekonomi Sebuah Ekplorasi Melalui Kata-Kata Kunci Dalam Al-Quran. Medan : Citapustaka Media Perintis

Chairuman Pasaribu. 1994. Hukum Perjanjian dalam Islam, cet. ke-1 .Jakarta: Sinar Grafika

Ika Novi Hidayati. 2017. Pengupahan dalam Perspektif Hukum Islam danHukum Positif. Jurnal Az Zarqa'. Vol. 9, No. 2

Imam Mustofa. 2016. Fiqih Muamalah Kontemporer, Jakarta: PT Raja Grafindo Persada

Haroen Nasroen. 2007. Fiqh Muamalah. Jakarta: Penerbit Gaya media Pratama

Hasan, Ali M. 2003.Berbagai Macam Transaksi dalam Islam. Ed. I. Cet. I; Jakarta: Raja Grafindo Persada

Hassan, Surtahman Kastin dan Abd. Ghafar Ismail. 2001. "Tenaga Buruh dan Upah dalam Islam". Dalam Islamiyyat No. 22: 3-12 (2001). Malaysia

Hendi Suhendi. 2002. Fiqh Muammalah. Jakarta: Raja Grafindo Persada

Ja'far Khumedi. 2016Hukum Perdata Islam di Indonesia. Bandar Lampung: Permatanet

Mannan, Muhammad Abdul. 1992. Ekonomi Islam: Teori dan Praktek (Dasar-dasar Ekonomi Islam); Terjemahan oleh Potan Arif Harahap, dari Islamic Economic: Theory and Practice. Jakarta: Intermasa 
Muhammad. 2005. Ekonomi Mikro dalam Perspektif Islam. Yogyakarta: BPFE-Yogyakarta.

M. Yazid Afandi. 2009. Fiqh Muamalah, Yogyakarta: Logunng Pustaka

Kementerian Agama RI. 2010. Al-Qur'an dan Tafsirnya. Jakarta

Qhardawi. 1997. Norma dan Etika Ekonomi Islam, alih bahasa Zainal Arifin dan Dahlia Husin. Jakarta: Gema Insani Press.

Ridwan, 2008. Regulasi Upah Dalam Fikih. Jurnal Al-Qalam. Vol 25. No 1

Sohari Sahrani dan Ru'fah Abdullah. 2011. Fikih Muamalah. Bogor: Galia Indonesia

Syafe'i Rahmad. 2001. Fiqih Muamalah, Bandung: Pustaka Setia

Zainuddin, SafwanRozi, Bustamar.2017. Tinjauan Fikih Terhadap Aktivitas Perdagangan di Pasar Bawah Bukittinggi, Jurnal Al-Risalah, Vol.17, No.2, hlm. 147-161 